Review Article

\section{Beginnings of bariatric and metabolic surgery in Spain}

\author{
Aniceto Baltasar* \\ Alcoy Hospital, Alicante, Spain
}

\section{Overview}

Bariatric Surgery (BS) from the Greek bari = weight and iatrein = cure) treats obesity and began in Spain in 1973. Its greatest development occurs after the founding of SECO (Spanish Society of Obesity Surgery) in 1997. The purpose of this work is to reflect the changes that have occurred in these 22 years.

Obesity is a multifactorial epidemic ailment of environmental origin, affecting subjects from all countries, and whose origins are not in the stomach or intestine. It represents a unique case of surgery to operate healthy organs, which are not the cause of the disease and do not improve after the operation.

Henryson [1] initiated Obesity Surgery (OS) in 1952. Kremen \& Linner [2] and Varco \& Buchwald in Minneapolis, MN teams began the malabsorptive intestinal diversion (ID) in 1954. Payne [3] and Scott [4] developed these ID techniques in the 1960s leaving only 14-4 inches (35-10 $\mathrm{cm}$ ) as an absorptive zone and those were abandoned in the 1970s because of their serious metabolic (malnutrition) and hepatic (liver failure) complications.

Buchwald [5] initiated the ID of the last third of the intestine for hypercholesterinemia (POSCH) and showed its protective role at 25 years in the development of atherosclerosis. Now it has also been abandoned, not because of lack of effectiveness, but because of the development of nystatin in the medical control of cholesterol. Dr. Henry Buchwald remains active 67 years later, and in 2012 Barcelona was appointed as Honorary Member of the Spanish Society of Obesity Surgery (SECO) and he will participate in MadridIFSO 2019. Baltasar [6] published in 1991 the only three ID in Spain for hypercholesterinemia.

\section{First spanish experience}

Prof. Sebastián García Díaz of Seville carried out the $1^{\text {st }}$ Scott-type Jejune-ileal diversion (JID) in the Virgen Macarena Hospital on 11.19.1973. He began bariatric surgery in Spain with 12 cases [7-10] and then published 20 more, the $1^{\text {st }}$

\begin{abstract}
More Information
*Address for Correspondence: Aniceto Baltasar, Alcoy Hospital, Alicante, Spain, Tel: +34-616 231 021; Email: abaltasar@coma.es

Submitted: 06 December 2019 Approved: 26 December 2019 Published: 27 December 2019

How to cite this article: Baltasar A. Beginnings of bariatric and metabolic surgery in Spain. Arch Surg Clin Res. 2019; 3: 082-090.

DOI: dx.doi.org/10.29328/journal.ascr.1001042 ORCiD: orcid.org/0000-0003-2964-8161
\end{abstract}

Copyright: (c) 2019 Baltasar A. This is an open access article distributed under the Creative Commons Attribution License, which permits unrestricted use, distribution, and reproduction in any medium, provided the original work is properly cited.

Keywords: Morbid obesity; Bariatric surgery; SECO

Abbreviations: VBG: Vertical Banded Gastroplasty; GB: Gastric Banding; RY-GBP: Roux-en-Y Gastric Bypass; OAGB: One Anastomosis GBP / mini GBP; BPD: Bilio-Pancreatic Diversion; ID: Intestinal Diversion; DS: Duodenal Switch; SADI: Single Anastomosis Duodenal-lleostomy; SFG: Sleeve-Forming Gastrectomy; ABS: Adolescent Bariatric Surgery; REV: Revision/Conversion of Prior Surgery; WL: Weight Loss; MO: Morbid Obesity; \%EWL: \% Excess Weight Loss; \%ExBMIL: \%Expected BMI Loss; L: Laparoscopic

(W) Check for updates

OPEn Access

work in English by a Spanish author [7] in the World Journal of Surgery in 1981 . For this $2^{\text {nd }}$ work he received the award by the Seville Hospital of the Five Sores in 1979 (Figure 1). His work went unnoticed for 40 years until we rescued them in 2013 [11].

There are two Spanish JID done by Drs. Sánchez/ Masdevall in Barcelona Bellvitge Hospital on March 1976 and another by Dr. Martínez, Zaragoza Clinic Hospital on July 12, 1978.

Buchwald [12] describe (Figure 2) the tree of the development of this surgery in the 1970s with a big malabsorptive and restrictive operation. The evolution of malabsorptive surgery is on the left, and restrictive surgery and gastric bypass (GBP) were reported.

In 1964 Mason [13] initiates the GBP. It was a total change in strategy. Capella [14], ÁlvarezCordero [15] (both 


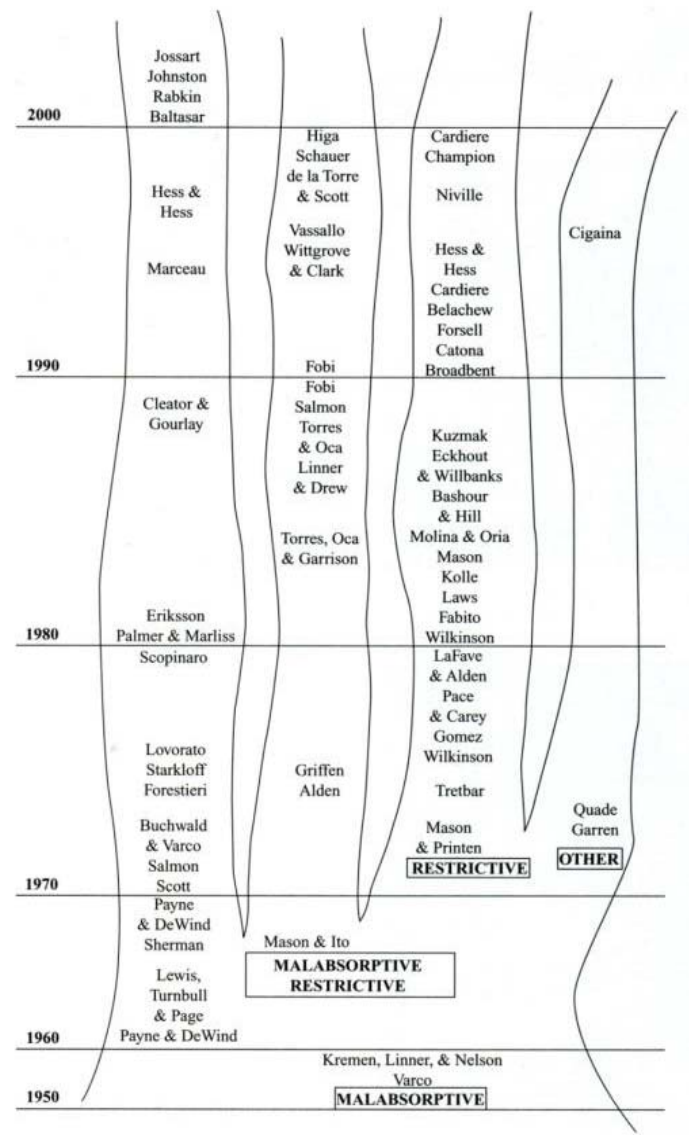

Figure 1: Bariatric techniques.

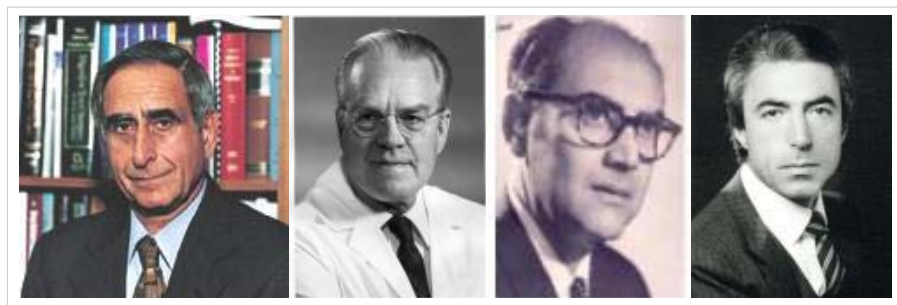

Figure 2: H. Buchwald, R. Mason, S. García, N. Scopinaro.

first SECO Honorary Members) and Fobi [16] made very important contributions to this technique and many other authors in the 1970s.

Baltasar [17] performed in June 17, 1977 the first Masontype GBP in Spain. Vara [18], De la Cruz [19] and Sitges [20] wrote in Spain about ID in hypercholesterinemia and GBP in obesity.

Scopinaro [21], a tireless researcher and clinician, initiated experimental and clinical gastrectomy with biliopancreatic diversion (BPD) in 1976 [22,23]. He is the leader and "father of European bariatric surgery" and participated in multiple congresses and publications. His combined mixed a technique of gastrectomy plus BPD as the most effective for treating obesity [24]. He is an Honorary Member of SECO and the only foreign Outstanding Achievement Award winner (OAAW) of the American Association of Metabolic and Bariatric Surgery (ASMBS).
DBP became a very popular and was a commonly used technique in Spain. Larrad and Sánchez [25-28] published extensively on a modification of their own and other authors used this technique in Zaragoza [29-32], Santander [33,34] and Barcelona.

Mason [35] "father of BS" published in 1982, 18 patients on vertical banded gastroplasty (VBG) and it was the $1^{\text {st }}$ great revolution by making OS "easy and affordable".

In 1984, Baltasar [36] broadcasts in RTVE the $1^{\text {st }}$ Spanish documentary in MO entitled "JJ Soriano more moral than the Alcoy man" with IMC-52 and that blocked the telephone lines of the hospital. Laporte [37] published the $1^{\text {st }}$ Spanish VBG experience in 9 cases.

Reopening of the vertical staple-line was a serious disadvantage of the VBG because it cancels out the restrictive effect of the operation. Baltasar [38] in 1989 described the separation with staples between gastric tube and major curvature and did not have a single recanalization in 100 cases. McLean [39] used the same technique three years later. Alcoy's Andreo [40] describes the typical radiological "peanut deformity" of the VBG.

Many Spanish surgeons performed VBG [41-43]. Baltasar [44] published his first 100 cases in 1990 with excellent results, but 5 years later he reviewed the same patients and describes it as a "frustrated hope" [45,46]. And two years later this technique was abandoned.

Belachew [47,48] in Belgium initiated on 1/09/1993 laparoscopy the $2^{\text {nd }}$ revolution in bariatrics with the $1^{\text {st }}$ laparoscopic adjustable gastric band (LAGB) operation.

Favretti [49] performed on Sept 27.1995 the $1^{\text {st }}$ LAGB operation in Spain at Madrid "La Paz" Hospital (Figure 3) assisted by Masdevall/baltasar Carbajo [50] in 1986 made the $1^{\text {st }} 12$ BGL in Spain and Alastrué [51] compares VBG with BGLA. Thousands of BGLA were done all over the world and then it was abandoned. Laparoscopy changed the way of doing surgery not only in BS but also in all general surgery. Advances in bariatric laparoscopy, being repetitive operations and performed on healthy organs were the greatest advance in XX century surgery.

In the 90 's the $1^{\text {st }}$ national bariatric societies were created, starting with the American Society of Bariatric Surgery (ASBS) by Edward Mason on June 3,1983 in Iowa City, IO [52], the town he worked all his life. Deitel created Obesity Surgery, as the $1^{\text {st }}$ journal of obesity in 1990 [52].
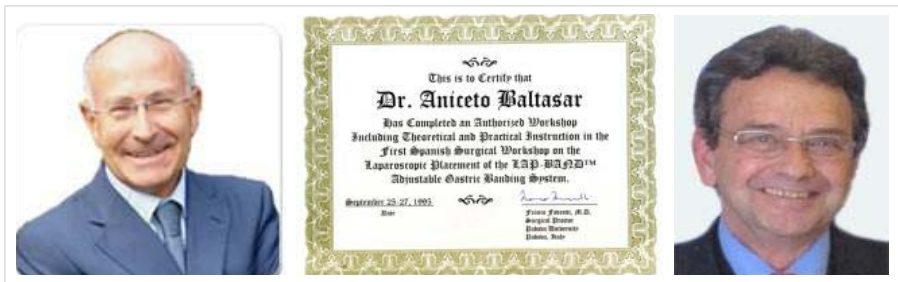

Figure 3: F. Favretti, $1^{\text {st }}$ Spanish LGB. "La Paz" Madrid. 1995 
In 1995 the International Federation of Surgery for Obesity (IFSO) is founded and standards [53] devised for reporting results.

The Spanish Society of Obesity Surgery (SECO) was founded at Residencia Pérez Mateos, San Juan, Alicante by 26 surgeons on December 12.1976 (Figure 5).

\section{SECO founding members}

December 12.1976 (Figure 6)

SECO joined IFSO in 1998 and AB became IFSO-2002 president. He organizes and preside IFSO-Salamanca-2003. Dr. Antonio Torres, $2^{\text {nd }}$ Spanish president of IFSO organizes IFSO-2019 Madrid, the world's largest bariatric meeting. Spain will be the $2^{\text {nd }}$ country that organizes this congress twice.

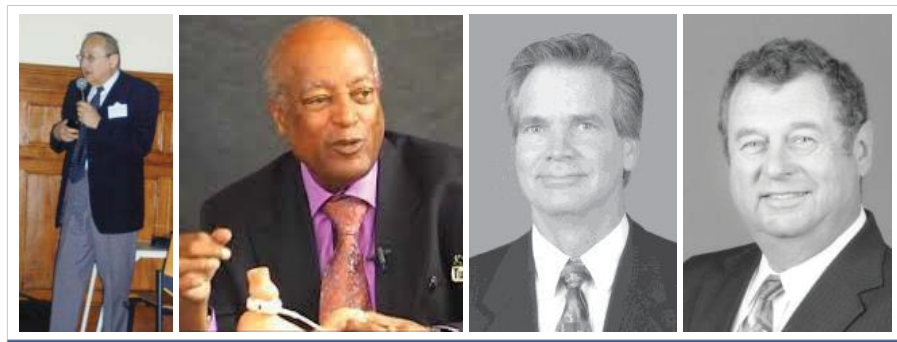

Figure 4: M. Deitel, M. Belachew, A. Wittgrove, W. Clark.

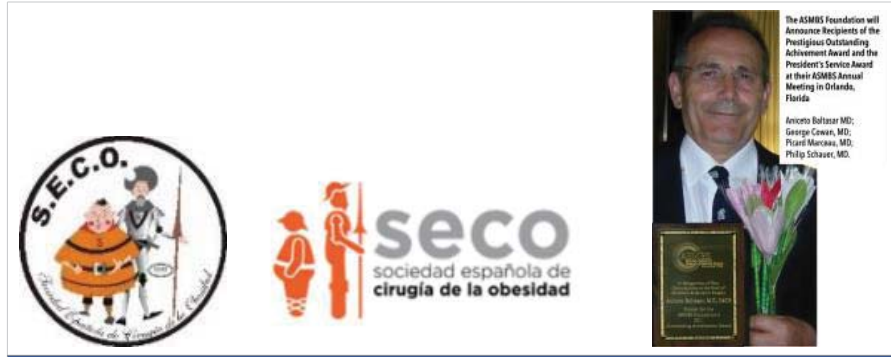

Figure 5: SECO-1976 SECO-2015 Baltasar-2011-AMSBS-OAAW.

San J uan. Alicante, España

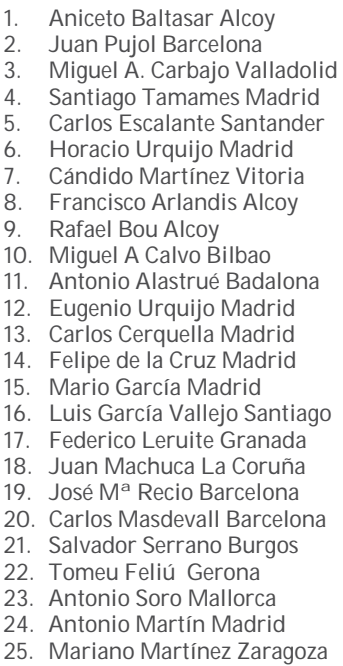

Figure 6: SECO Founding members.
Wittgrove and Clark in October 27, 2003 [55-57] made the most significant step in performing the $1^{\text {st }}$ laparoscopic gastric bypass (LGBP) in San Diego. This is the $3^{\text {rd }}$ revolution of the BS. AB was the $1^{\text {st }}$ visitor in September 2007 in San Diego, and to our proposal Wittgrove [58] dropped the huge circular \#33 port and use the circular stapler without trocar, a very important step in those early times.

We performed the $1^{\text {st }}$ LGBP in Spain on 1.14.1997 [59] and presented it [60] at Bruges IFSO-1998 the $1^{\text {st }}$ European to report it on video. Serra [61] published in 1999 the $1^{\text {st }}$ world hernia after LGBP. Higa [62] made fortunately the $1^{\text {st }}$ LGBPs with manual sutures.

Baltasar [63] published the $1^{\text {st }}$ book in Spanish in OS in 2000. Martínez [64] from Vitoria published a bilingual BS book (Spanish and Basque) on 2001. De la Cruz [65] published in 2006 the $1^{\text {st }}$ book on LGBP in Spain and carried out the $1^{\text {st }}$ surgical session in León. García-Caballero published an English book on diabetes surgery (Figure 7).

In 1988, Hess [66] and Marceau [67] initiated the duodenal switch (DS), a Sleeve-forming Vertical Gastrectomy (SFVG) plus BPD and Baltasar [68] started it on 3.17.1994.

Ren/Gagner [69] performed the $1^{\text {st }}$ world LDS in October 1999 and Baltasar on 5.10.2000 [70] the $1^{\text {st }}$ LDS in Europe. (Figure 8). This difficult and controversial technique by the Switchers surgeons, is rarely used today, in less than $1 \%$.

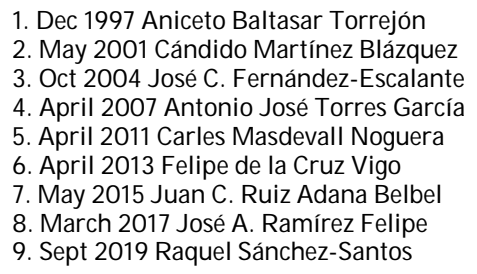

Figure 7: SECO Presidents.

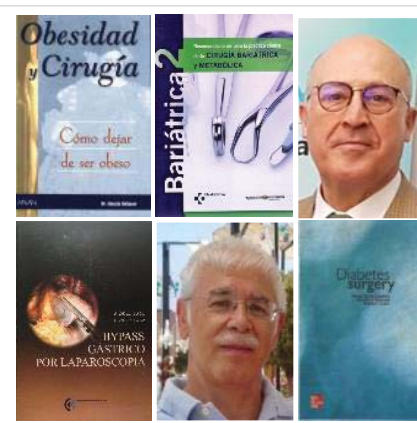

Figure 8: Baltasar-2000, C. Martínez, De la Cruz, Diabetes de Caballero. Books published by SECO members.

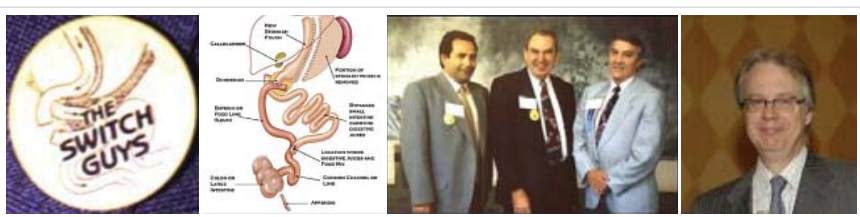

Figure 9: Switchers logo DS, AB/Hess/Marceau, M. Gagner. 
Baltasar [71] on 950 patients had a low mortality of $0.4 \%$ with LDS and is the most effective technique to lose weight. There have been many technical variations in laparoscopy. In general, all viscera division is done with auto sutures. The anastomosis is done either with auto sutures or manual ones. We advocate the manual suture starting always with the sliding, self-locking sliding knot of Serra - Baltasar [72,73].

SECO members reported BS surgeries in the early years of OS and SOARD. Spain was the $2^{\text {nd }}$ country with the highest number of publications after the USA in 2005 and 2006 and in 2013 was the $5^{\text {th }}$ country with the highest number of publications in SOARD (Figure 10).

SECO members have been very active publishing in OS and SOARD (Figures 8,9). Among the SECO founding members there has been a high bibliographic volume (Alcoy-124, Carbajo-76, Belvitge-38, Alastrué-30, Martín-Duce-27, Martínez C.-22, Ballesta-9, Zaragoza-5). In 2003 SECO made the Salamanca Declaration on BS [74].

Laparoscopic Sleeve-forming gastrectomy (LSFG), the restriction part of DS, was so described by several authors in

\begin{tabular}{|c|c|c|c|}
\hline \multicolumn{5}{|c|}{ Paters in Obesity Surgery. } \\
\hline Argentina & 1 & Korea & 1 \\
\hline Australia & 7 & Mexico & 1 \\
\hline Austria & 5 & New Zealand & 2 \\
\hline Belgium & 6 & Netherlands & 3 \\
\hline Brazil & 20 & Poland & 4 \\
\hline Canada & 6 & Saudi Arabia & 3 \\
\hline Chile & 4 & Spain & 31 \\
\hline France & 20 & Sweden & 1 \\
\hline Germany & 3 & Switzerland & 5 \\
\hline Greece & 8 & Taiwan & 1 \\
\hline Iceland & 1 & Turkey & 2 \\
\hline Israel & 6 & United Kingdom & 4 \\
\hline Italy & 20 & USA & 84 \\
\hline & & Total & $\mathbf{2 5 0}$ \\
\hline
\end{tabular}

\begin{tabular}{|c|c|c|c|c|c|}
\hline Argentina & 3 & Germany & 10 & Russia & 1 \\
\hline Australia & 11 & Greece & 12 & Saudi Arabia & 2 \\
\hline Austria & 13 & Israel & 10 & Singapore & 2 \\
\hline Belgium & 12 & Italy & 25 & Spain & 33 \\
\hline Brazil & 27 & Korea & 3 & Sweden & 5 \\
\hline Canada & 8 & Kuwait & 1 & Switzerland & 12 \\
\hline Chile & 5 & Lebanon & 2 & Taiwan & 7 \\
\hline China & 3 & Mexico & 2 & Turkey & 3 \\
\hline Cyprus & 1 & New Zealand & 4 & United Kingdom & 7 \\
\hline Czech Republic & 2 & Netherlands & 9 & USA & 106 \\
\hline Finland & 1 & Poland & 5 & & \\
\hline France & 24 & Portugal & 3 & Total & 374 \\
\hline
\end{tabular}

Publicaciones españolas de SECO en Obes. Surg. 2005-6.

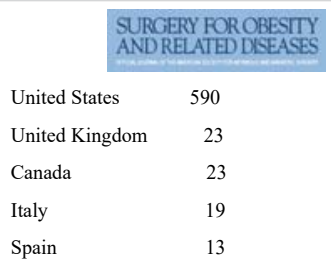

Figure 10: Spanish publications in SOARD 2014.
2005. Baltasar LSFG [75], according to Ahmad [76] is the $61^{\text {st }}$ most cited article in all the bariatric literature. Angrisani [77] claims that the LSFG is today the most commonly performed operation in the world.

We start the gastrectomy at the pylorus and suture the gastric anterior and posterior serosa, covering the staples, to prevent rotation of the sleeve and avoid leaks.

Rutledge described 1,274 cases of mini-gastric bypass in 2001 [78] and Spanish authors have developed two popular techniques. Carbajo [79] performs since 2004 the lesser curvature reservoir without gastric resection, the one anastomosis OAGB, a GBP with latero-lateral diversion to an intestinal loop. He presented more than 3,500 cases at the 1919s World Congress in Valladolid and is today the fasters growing technique in the world (Figure 11).

Sánchez and Torres [80] at Madrid Clinic Hospital, describe in 2005 the one anastomosis DS or SADI in English. There is gastric resection in the form of SFG and the BPD is done end-toside at the duodenum (D1). The operation is becoming very popular all over the world. Currently they have more than 350 cases (Figure 12).

BS at Barcelona Bellvitge hospital has organized 16 consecutive bariatric courses and Torres/Sánchez another 16 annual courses at Madrid Clinic Hospital.

We founded BMI-Latina Journal (Iberoamerican Bariatric and Metabolic) www.bmilatina.com in 2011 as an online magazine published in Spanish, English and Portuguese. Adopted by SECO in 2015, it should play a valuable role in Spanish and Portuguese speaking BS societies but since 2015 only the abstract is published in English, and that may restrict its dissemination.

In 2009, Scopinaro, Melissas, Fried and $A B$ create the

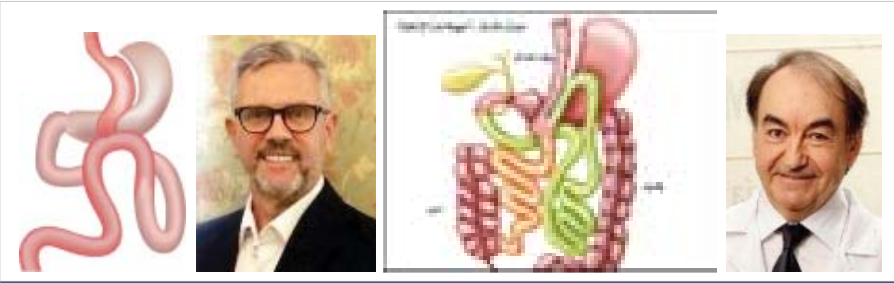

Figure 11: OAGP R. Rutledge; OAGBP MA. Carbajo.
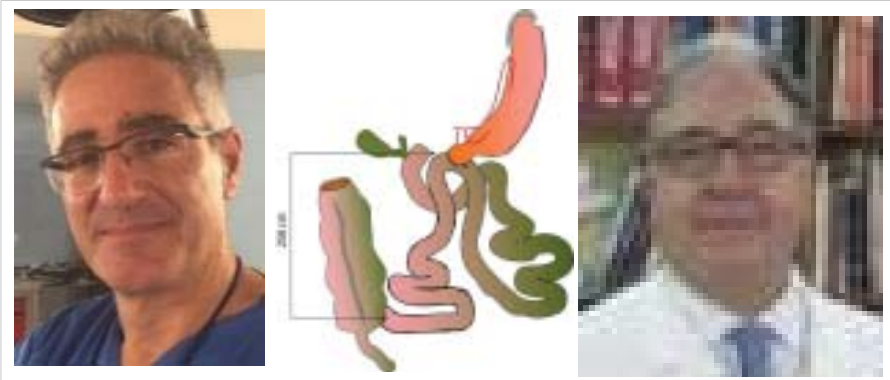

Figure 12: A. Sánchez; SADI; A. Torres. 
IFSO European Chapter of the Centers of Excellence Program (ECEP). Currently, several Spanish centers and surgeons use this prestigious quality control program.

SECO members have participated in numerous local, regional, national, and international meetings and congresses, especially in Latin American societies where SECO has always been very kindly well received. In May 1998 we organized a table at the meeting of the prestigious course of Prof. Moreno González, with Drs. Cowan, Fobi, Scopinaro, Clark \& F.de la Cruz.

In 2003, $\mathrm{AB}$ inaugurated the Spring (NYC) and Fall (Chicago) two keynote lectures at the American Congress of Surgery with on DS.

$\mathrm{AB}$ received the IFSO-Lifetime Membership Award in June 2011 and was a finalist for the prestigious ASMBSOutstanding Achievement Award at the ASMBS meeting in Orlando, Florida (Figure 4).

\section{Diabetes surgery}

Part of the BS is dedicated to diabetes as metabolic surgery. Baltasar [80] publishes a successful $1^{\text {st }}$ intervention in 2004 BPD-without-SFG.

Resa and Solano [82] describe 65 cases of gastroileal bypass as the simplest, quickest and safest technique we know for treating obesity. And then Resa [83] again publishes 1512 more cases. Alhambra [84], Vidal [85], Vilarrasa [86], García [87], Cruz [88] and Torres [89] have published on the same subject.

\section{Laparoscopic OS in Children and Adolescents (ABS)}

OS is increasingly used in children. Baltasar [90,91] published the $1^{\text {st }}$ national SFG in 2004 on a 10 -year-old boy with excellent results 10 years later.

Carbajo [92] has a case with 5 years follow-up and then in 2019 again [93] reports the more extensive experience in CLONA with 39 patients treated with OAGBP with excellent results.

Vilallonga [94] reports that the overweight rate in 4-24 years-old children has increased by approximately $10 \%$ in the last 20 years. It is estimated that today, $20 \%$ of boys and teenagers and $15 \%$ of girls are overweight.

\section{Robotics bariatric surgery}

Cadiere and Favretti performed the world's $1^{\text {st }}$ robotic
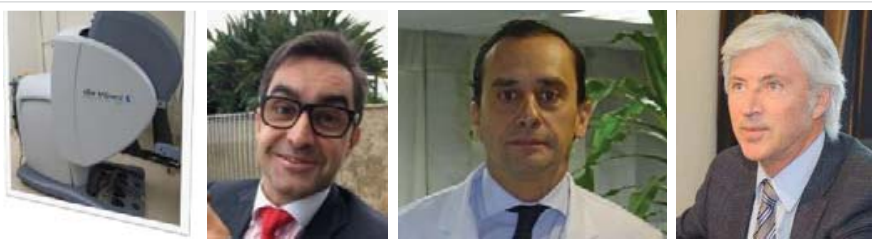

Figure 13: Da Vinci R. Vilallonga; S. Morales; A. Lacy. bariatric operation at a distance in 1998. Diez and Blázquez perform the first 12 robotic Spanish bariatric surgeries in Vitoria-2013. Vilallonga ( $1^{\text {st }}$ accredited robotics surgeon in Spain) and Fort from 2010 in the Hospital Vall d'Hebron in Barcelona develop robotic surgery [94] and performed more than 540 cases with the da Vinci (Figure 13). Surgical System $^{\circledR}$ (Intuitive Surgical, Sunnyvale, CA) at the beginning with GV and them DG robotics [95].

Morales [96] performs in Seville the complex single port surgery of since 2012 and today leads the European surgery [97].

A. Lacy initiated AIS-Channel as a pioneering worldwide on-line TV transmission and made the $1^{\text {st }} \mathrm{BS}$ remote operation by cellphone G5 from Barcelona Clinic Hospital on 4.14.2019 at the WORLD-VIDEO Forum Barcelona-2019.

The biography of members of the Spanish society [98101] has been published in the Obes. Surg.

\section{Surgeries performed in Spain 2018}

$1^{\text {st }}$ Surgeries: $5.952 ; 2^{\text {nd }}$ Revision: 343 :

Total Complications: LGBP-3.7\% and LSFG-3.6\%; LGBP-Leaks-1.2\%, Bleeding-2.3\%, PET-0.1\% Re-op-2.3\% Exitus-0.1\% and in SFG-Leaks-1.5\%, Bleeding-1.9\% PET$0.1 \% 2.1 \%$ Deaths-0.1\%. Extraordinary good results!

Private centers report multiple operations over the years with different techniques: Valladolid-4.255, Teknon-3.000, De la Cruz-2.493, Zaragoza-2.649, Alcoy-1.729.

We should publish all serious complications such as malnutrition [105], leaks [106,107], total gastrectomy's [108], liver failure [109,110], stapling of the bougie [111], emergency tracheostomy[112] and mistakes as the Journal of negatives or non-positive results (JNNPR) [114], since it is more likely to learn from negative results than positive ones.

BS is performed in public centers in all regions of Spain with very low leakage and complication rates. But... it is not yet performed on an outpatient basis.

If $\mathrm{OM}$ is an epidemic pathology and if $\mathrm{CB}$ is the best solution, it should be accessible to more subjects. Duncan [109] performs ambulatory BS, and this will be the 4th great bariatric revolution. His A-team uses 2 operating rooms, 2 anesthesiologist nurses, 2 scrub nurses and an operating room technician as an assistant. Operative times of 22 '. The surgeon passes to OR- 2 with the patient already anesthetized. He changes gloves and do 5 patients in total in the morning. In the afternoon, surgeon-B operates while team-A have consultations. Total 10 patients per day. 50 cases per week, 2,2000 cases per year. No overnight stay. All morning patients are discharged before 14 hours. There is no hospitalization. 


\section{References}

1. Henrikson V. Kantunn farmsresektion forsvaras som terapi mot fett sot? Nordisk Medicin. 1952; 47: 744.

2. Kremen $\mathrm{AJ}$, Linner $\mathrm{JH}$, Nelson $\mathrm{CH}$. An experimental evaluation of the nutritional importance of proximal and Distal small intestine. Ann Surg. 1954; 140: 439-448.

PubMed: https://www.ncbi.nlm.nih.gov/pubmed/13198079

3. Payne JH, de Wind L, Schab CE, Kern WH. Surgical treatment of morbid obesity. Sixteen years of experience. Arch Surg. 1973; 106: 431-437. PubMed: https://www.ncbi.nlm.nih.gov/pubmed/4696715

4. Scott HW, Law DH, Sandstead H, Lanier VC Jr, Younger RK. Jejunoileal shunt in surgical treatment of morbid obesity. Ann Surg. 1971; 171: 770-781.

PubMed: https://www.ncbi.nlm.nih.gov/pubmed/5445664

5. Buchwald H, Williams SE, Matts JP, Nguyen PA, Boen JR. Overall mortality in the program of the surgical control of the hyperlipidemias (POSCH). J Am Coll Surg. 2002; 195: 327-331.

6. Baltasar A, Marcote E, Bou R, Bengochea M, Arlandis F. Exclusión ileal parcial en la hiper colesterinemia. Apropósito de tres operaciones. Cir Esp. 1991; 6: 4475-4478.

7. García Díaz S. Indicaciones del tratamiento quirúrgico en la obesidad mórbida. Rev Quir Española. 1975; 2: 165-172.

8. García Díaz S, Pera C, Loscertales J. Trabajos originales. Estado actual del tratamiento de cirugía de la obesidad. Rev Esp Enf del Ap Digestivo. 1977; 51: 1-25.

9. García Díaz S, Pera C, Loscertales J. Avances en cirugía. Barcelona Editorial Salvat. 1979; 209-224.

10. García Díaz S, García G. Medical and surgical indications for treatment of morbid obesity. World J Surg. 1981; 5: 795-799.

PubMed: https://www.ncbi.nlm.nih.gov/pubmed/7342473

11. Baltasar A. Domínguez-Adame E. Inicios de la cirugía bariátrica y metabólica en España. Cir Esp. 2013; 91: 407-416.

12. Buchwald H, Rucker R. The History of Metabolic Surgery for Morbid Obesity and a Commentary. World J Surg. 1981; 5: 781-787.

PubMed: https://www.ncbi.nlm.nih.gov/pubmed/7043911

13. Mason EE, Ito C. Gastric bypass in obesity. Surg Clin North Am. 1967; 47: 1345-1351.

PubMed: https://www.ncbi.nlm.nih.gov/pubmed/6073761

14. Capella R, Capella J, Mandac H. Vertical Banded Gastroplasty-Gastric Bypass: preliminary report. Obes Surg. 1991; 1: 389-395. PubMed: https://www.ncbi.nlm.nih.gov/pubmed/10775940

15. Álvarez-Cordero R, Aragon V. Post-operative Complications in a Series of Gastric Bypass Patients. Obes Surg. 1992; 2: 87-89. PubMed: https://www.ncbi.nlm.nih.gov/pubmed/10765170

16. Fobi M. Why silastic ring vertical banded gastric bypass for treatment of obesity? Obes Surg. 1991; 1: 423-426.

PubMed: https://www.ncbi.nlm.nih.gov/pubmed/10775946

17. Baltasar A, Del Río J, Bengochea A. Bypass gástrico en la obesidad mórbida. Revista clínica Española. 1980; 157: 395-399.

18. Vara López R. Tratamiento quirúrgico de la obesidad. Real Academia de Medicina. Anales XCI. 1974

19. De la Cruz Caro F. Mesa redonda sobre obesidad. Mayo. 1975.

20. Sitges Creus A, Laporte E. Tratamiento quirúrgico de la obesidad masiva. Práctica quirúrgica. 1982.
21. Scopinaro N, Gianetta E, Civalleri D, Bonalumi U, Bachi V. Biliopancreatic bypass for obesity: II. Initial experience in man. $\mathrm{Br} \mathrm{J}$ Surg. 1979; 66: 619-620.

PubMed: https://www.ncbi.nlm.nih.gov/pubmed/497645

22. Scopinaro N, Gianetta E, Civalleri D, Bonalumi U, Bachi V. Two years of clinical experience with bilio-pancreatic bypass for obesity. Am J Clin Nutr. 1980; 33: 506-514.

PubMed: https://www.ncbi.nlm.nih.gov/pubmed/7355830

23. Scopinaro N, Gianetta E, Civalleri D, Bonalumi U, Friedman D, et al. Partial and total biliopancreatic bypass in the surgical treatment of obesity. Int J Obes. 1981; 5: 421-429.

PubMed: https://www.ncbi.nlm.nih.gov/pubmed/7309327

24. Scopinaro N. Why the Operation I Prefer is Biliopancreatic Diversion (BPD). Obes Surg. 1991; 1: 307-309.

PubMed: https://www.ncbi.nlm.nih.gov/pubmed/10775931

25. Sánchez C, Larrad N. Analysis of Weight Loss with the Biliopancreatic Diversion of Larrad: Absolute Failures or Relative Successes? Obes Surg. 2002; 12: 249-252.

PubMed: https://www.ncbi.nlm.nih.gov/pubmed/11975222

26. Larrad A, Sánchez C. Quality indicators in bariatric surgery and criteria for long-term success. Cir Esp. 2004; 75: 301-304.

27. Larrad A, Sánchez C, Cuadros P, Ramos García I, Moreno Esteban B, et al. Course of Metabolic Syndrome following the Biliopancreatic Diversion of Larrad. Obes Surg. 2007; 17: 202-210. PubMed: https://www.ncbi.nlm.nih.gov/pubmed/15527630

28. Larrad A, Sánchez C, Cuadros P, Lesmes IB, Esteban BM. Short-, Midand Long-Term Results of Larrad Biliopancreatic Diversion. Obes Surg. 2007; 17: 202-210.

PubMed: https://www.ncbi.nlm.nih.gov/pubmed/17476873

29. Elía M, Ariba's D, Gracia J, Artigas C, Bernadó AJ, et al. Results of biliopancreatic diversion after five years. Obes Surg. 2004; 14: 766-772. PubMed: https://www.ncbi.nlm.nih.gov/pubmed/15318979

30. Gracia J, Martínez M, Aguilella V, Elia M, Royo P. Postoperative morbidity of biliopancreatic diversion depending on common limb length. Obes Surg. 2007; 117: 1306-1311.

PubMed: https://www.ncbi.nlm.nih.gov/pubmed/18098399

31. Aguilella $V$, Royo $P$, Jiménez $A$, Aguilella $V$, Royo $P$, et al. Obesity surgery results depending on technique performed: long-term outcome. Obes Surg. 2009; 19: 432-438.

PubMed: https://www.ncbi.nlm.nih.gov/pubmed/19002740

32. Gracia JA, Elía M, Aguilella V, Ramirez JM, Martínez J, et al: Metabolic syndrome after bariatric surgery. Results depending on the technique performed. Obes Surg. 2011; 21: 179-185.

PubMed: https://www.ncbi.nlm.nih.gov/pubmed/21080097

33. Domínguez A, Olmedo F, Ingelmo A, Gómez M, Escalante C. Bypass biliopancreático. Cir Esp. 2004; 75: 251-256.

34. Palomar R, Fernández G, Domínguez A, López-Deogracias M, Olmedo $F$, et al. Effects of Weight Loss after Biliopancreatic Diversion on Metabolism and Cardiovascular Profile. Obes Surg. 2005; 15: 794-798. PubMed: https://www.ncbi.nlm.nih.gov/pubmed/15978149

35. Mason E. Vertical banded gastroplasty for obesity. Arch Surg. 1982; 117: 191-194.

36. Baltasar A. "JJ Soriano más moral que el alcoyano". RTVE Vivir cada día.

37. Laporte E, Badosa F, Masdevall C. La gastro plastia para el tratamiento de la obesidad. Cir Esp. 1985; 38: 621-625.

38. Baltasar A. Modified vertical gastroplasty. Technique with vertical division and serosal patch. Acta Chir Scand. 1989; 155: 107-112. PubMed: https://www.ncbi.nlm.nih.gov/pubmed/2741612 
39. McLean LD, Rhode BM, Sampalis J, Forse RA. Results of the surgical treatment of obesity. Am J Surg. 1993; 165: 155-162. PubMed: https://www.ncbi.nlm.nih.gov/pubmed/8418692

40. Andreo L, Lasierra R, Baltasar A. Evaluación radiológica de la gastroplastia vertical anillada. Radiología. 1988; 30: 303-308.

41. Alastrué A, Rull M, Casas D. Gastroplastia vertical anillada. Experiencia de un grupo multidisciplinario en 65 pacientes. Metodología y técnica quirúrgica. Resultados antropométricos. Cir Esp. 1991; 50: 50-58.

42. Alastrué A, Formiguera J, Rull M, Casas D, Escudero LE, et al. Cirugía bariátrica: gastroplastia vertical anillada. Obesidad mórbida y super obesidad. Resultados antropométricos. Complicaciones técnicas y reintervenciones a largo plazo. Rev Endocrinol. 1992; 38: 365-375.

43. Arribas D, Martínez M, Elía M, Diago VA. Vertical banded gastroplasty: Is it a durable operation for morbid obesity? Obes Surg. 2004; 14: 536538.

PubMed: https://www.ncbi.nlm.nih.gov/pubmed/15130234

44. Baltasar A, Tomás, Marcote. Cirugía bariátrica. Experiencia con 100 pacientes operados. Cir Esp. 1991; 50: 271-275.

45. Baltasar A, Bou R, Del Río J. Cirugía bariátrica: resultados a largo plazo de la gastroplastia vertical anillada. ¿Una esperanza frustrada? Cir Esp. 1997; 62: 175-179.

46. Baltasar A, Bou R, Arlandis F, Martínez R, Serra C, et al. Vertical banded gastroplasty at more than five years. Obes Surg. 1998; 8: 29-34. PubMed: https://www.ncbi.nlm.nih.gov/pubmed/9562483

47. Belachew M, Lagrard TH, Defrebreuren M. Laparoscopic adjustable silicone gastric banding in the treatment of morbid obesity. Surg Endosc. 1994; 8: 1354-1356.

PubMed: https://www.ncbi.nlm.nih.gov/pubmed/7831615

48. Belachew $M$, Legrand $M$, Vincent $V$, Deffechereux $T$, Jourdan $\mathrm{JL}$, et al. Laparoscopic Placement of Adjustable Silicone Gastric Band in the Treatment of Morbid Obesity: How to Do It. Modern Surgery: Technical Innovations. Obes Surg. 1995; 5: 66-70.

PubMed: https://www.ncbi.nlm.nih.gov/pubmed/10733796

49. Favretti F, Cadiere GB, Segato G, Bruyns G, De Marchi F, et al. Laparoscopic Adjustable Silicone Gastric Banding: Technique and Results. Obes Surg. 1995; 5: 364-371.

PubMed: https://www.ncbi.nlm.nih.gov/pubmed/10733827

50. Carbajo MA, Martín JC, Blanco J. Banda ajustable por laparoscopia (Lapband) en el tratamiento de la obesidad grave. Experiencia preliminar Cir Esp. 1998; 63: 185-188.

51. Alastrué A, M Rull, D Casas. Evaluación de dos técnicas restrictivas en cirugía bariátrica. Gastroplastia vertical anillada (GVA) vs bandeleta hinchable (Lapband). Valoración a los dos años. Cir Esp. 1996; 60: 181-187.

52. Scott HW. A tribute to Edward E Mason. The 1st Annual Edward E. Mason Founders lecture. Obes Surg. 1991; 1: 13-19.

53. Blommers T. The ASBS first nine years. Obes Surg. 1992; 2: 115-117

54. Mason E, Amaral J, Cowan G, Deitel E, Gleysteen JJ, et al. Standards for reporting results. Obes Surg. 1994; 4: 56-65.

PubMed: https://www.ncbi.nlm.nih.gov/pubmed/10742766

55. Wittgrove A, Clark W, Tremblay L. Laparoscopic gastric bypass. Rouxen-Y. Preliminary report. Obes Surg. 2004; 4: 353-357.

PubMed: https://www.ncbi.nlm.nih.gov/pubmed/10742801

56. Wittgrove A, Clark W. Laparoscopic gastric bypass. Roux-en Y. Experience with 27 cases with 3-18 months follow up. Obes Surg. 2006; 6: 54-57.

PubMed: https://www.ncbi.nlm.nih.gov/pubmed/10731251
57. Wittgrove A, Clark W, Schubert K. Laparoscopic gastric bypass. Rouxen $Y$. Technique and results in 75 patients with 3-30 months follow up. Obes Surg. 2006; 6: 500-504.

PubMed: https://www.ncbi.nlm.nih.gov/pubmed/10729899

58. Wittgrove A. Chapter 21: Laparoscopic gastric bypass. Circular stapler technique. In: Obesity Surgery: Principles and Practice. Pitombo C, Jones KB, Higa KD, Pareja JC). Albany, New York: McGraw Hill Medical. 2007; 221-224.

59. Baltasar A, Bou R, Miró J, Serra C. Bypass gástrico por laparoscopia. Cir Esp. 2000; 67: 556-559.

60. Baltasar A, Bou R, Bengochea M. Lap Roux-Y gastric bypass. V-18. Obes Surg. 1998; 8: 393

61. Serra C, Baltasar A, Bou R, Miró J, Cipagauta LA. Internal hernias and gastric perforation after laparoscopic gastric bypass. Obes Surg. 1999; 9: 546-549.

PubMed: https://www.ncbi.nlm.nih.gov/pubmed/10638480

62. Higa K, Boone K, Ho T. Complications of the Laparoscopic Roux-en-Y Gastric Bypass: 1,040 Patients - What Have We Learned? Obes Surg. 2000; 10: 509-513.

PubMed: https://www.ncbi.nlm.nih.gov/pubmed/11175957

63. Baltasar A. Obesidad y cirugía. Cómo dejar de ser obeso. Libro de Editorial Arán. 2000.

64. Martínez C. Martínez G. Bypass gástrico laparoscópico. Vitoria. 2001.

65. De la Cruz F, la Cruz JL. Bypass Gástrico por Laparoscopia Laparoscopic Gastric Bypass. Obes Surg. 2006; 16: 112.

66. Hess DS, Hess DW. Biliopancreatic diversion with a duodenal switch. Obes Surg. 1988; 8: 267-282.

67. Marceau P, Biron S, Bourque RA, Potvin $M$, Hould FS, et al. Biliopancreatic Diversion with a New Type of Gastrectomy. Obes Surg. 1993; 3: 29-35.

PubMed: https://www.ncbi.nlm.nih.gov/pubmed/10757900

68. Baltasar M, Bou R, Cipagauta LA, Marcote E, Herrera GR, et al. Hybrid bariatric surgery: Biliopancreatic diversion and duodenal switch. Obes Surg. 1995; 5: 419-423.

PubMed: https://www.ncbi.nlm.nih.gov/pubmed/10733838

69. Ren CJ, Patterson E, Gagner M. Early results of laparoscopic biliopancreatic diversion with duodenal switch: a case series of 40 consecutive patients. Obes Surg. 2000; 10: 514-523. PubMed: https://www.ncbi.nlm.nih.gov/pubmed/11175958

70. Baltasar A, Bou R, Miró J. Avances en técnica quirúrgica. Cruce duodenal por laparoscopia en el tratamiento de la obesidad mórbida: técnica y estudio preliminar. Cir Esp. 2001; 70: 102-104.

71. Aniceto Baltasar, Nieves Pérez, Rafael Bou, Marcelo Bengochea, Carlos Serra. A switch to the Duodenal Switch. Glob J Obes Diabetes Metab Syndr. 2019; 6: 001-009.

72. Serra C, Pérez N, Bou R, Baltasar A. Sliding Self-Locking First Stitch and Aberdeen Knots in Suture Reinforcement with Omentoplasty of the Laparoscopic Gastric Sleeve Staple line. Obes Surg. 2014; 24: 1739-1740.

PubMed: https://www.ncbi.nlm.nih.gov/pubmed/25085221

73. Baltasar A, Bou R, Serra R, Bengochea M, Pérez N. Use of self-locking knots in running intestinal bariatric sutures. Glob Surg. 2015; 2: 100101.

74. Recomendaciones de la SECO para la práctica de la cirugía bariátrica (Declaración de Salamanca). Cir Esp. 2004; 75: 312-314.

75. Baltasar A, Serra C, Pérez N, Bou R, Bengochea M, et al. Laparoscopic 
sleeve gastrectomy: A multi-purpose operation. Obes Surg. 2005; 15 : 1124-1128.

PubMed: https://www.ncbi.nlm.nih.gov/pubmed/16197783

76. Ahmad SS, Ahmad SS, Kohl S. The Hundred Most Cited Articles in Bariatric Surgery. Obes Surg. 2015; 25: 900-909.

PubMed: https://www.ncbi.nlm.nih.gov/pubmed/25720513

77. Angrisani L, Santonicola A, lovino P, Vitiello A, Higa K, et al. IFSO Worldwide Survey 2016: Primary, Endoluminal, and Revisional Procedures. Obes Surg. 2018; 28: 3783-3794.

PubMed: https://www.ncbi.nlm.nih.gov/pubmed/30121858

78. Rutledge R. The Mini-Gastric Bypass: Experience with the First 1,274 Cases. Obes Surg. 2001; 11: 276-280.

PubMed: https://www.ncbi.nlm.nih.gov/pubmed/11433900

79. Carbajo M, García M, Toledano M, Osorio D, García-Lanza C, et al. One anastomosis gastric bypass by laparoscopy: results of the first 209 patients. Obes Surg. 2004; 15: 398-404.

PubMed: https://www.ncbi.nlm.nih.gov/pubmed/15826476

80. Sánchez-Pernaute A, Rubio Herrera MA, Pérez-Aguirre E, García Pérez JC, Cabrerizo L, et al. Proximal Duodenal-lleal End-to-Side Bypass with Sleeve Gastrectomy: Proposed Technique. Obes Surg. 2007; 17: 1614-1618.

PubMed: https://www.ncbi.nlm.nih.gov/pubmed/18040751

81. Baltasar A. Historical note: First diabetes metabolic operation in Spain. Integr Obesity Diabetes. 2015.

82. Resa J, Solano J, Fatás A, Blas JL, Monzón A, et al. Laparoscopic Biliopancreatic Diversion: Technical Aspects and Results of our Protocol. Obes Surg. 2004; 14: 329-333.

PubMed: https://www.ncbi.nlm.nih.gov/pubmed/15072652

83. Resa Bienzobas J, Lagos Lizan J, Pérez Zapata Al. Laparoscopic Gastro ileal Bypass with Single Anastomosis: Analysis of the First 1512 Patients. Laparoscopic Gastroileal Bypass with Single Anastomosis. Obes Surg. 2019; 1976-1981.

84. Alhambra M, Molina M, Prior M, Manzano-García G, CalañasContinente $A$, et al. Variations in diabetes remission rates after bariatric surgery in Spanish adults according to the use of different diagnostic criteria for diabetes. BMC Endocr Disord. 2017; 17: 51. PubMed: https://www.ncbi.nlm.nih.gov/pubmed/28810850

85. Vidal J, Ibarzabal A, Romero F, Delgado S, Momblán D, et al. Type 2 diabetes mellitus and the metabolic syndrome following sleeve gastrectomy in severely obese subjects. Obes Surg. 2008; 18: 10771082.

PubMed: https://www.ncbi.nlm.nih.gov/pubmed/18521701

86. Vilarrasa N, Rubio MA, Miñambres I, Flores L, Caixàs A, et al. Longterm outcomes in patients with morbid obesity and Type 1 Diabetes Undergoing Bariatric Surgery. Obes Surg. 2017; 27: 856-863. PubMed: https://www.ncbi.nlm.nih.gov/pubmed/27709487

87. García M, Tinahones FG, Cohen R. McGraw-Hill Interamericana de España S.L. $1^{\text {a }}$ ed., $1^{\text {a }}$ imp.

88. Cruz M, Rubio MA, Calle L. Remisión de diabetes mellitus tipo 2 a largo plazo tras cirugía bariátrica Tesis. Hospital Clínico. 2017.

89. Torres A, Sánchez A, Rubio MA. Metabolic surgery for obesity a critical account. Endocrinol Nutr. 2013; 60: 36-38.

PubMed: https://www.ncbi.nlm.nih.gov/pubmed/24490225

90. Baltasar A, Serra C, Bou R, Bengochea M, Andreo L. Sleeve Gastrectomy in a 10-year-old Child. Obes Surg. 2008; 18: 733-736. PubMed: https://www.ncbi.nlm.nih.gov/pubmed/18401672

91. Baltasar A. Nine years follow up of the 1st Adolescent Bariatric
Surgery in Spain Nine years follow up of the 1st Adolescent Bariatric Surgery in Spain. J Obes. 2017; 3: 026.

92. Carbajo $M$, Vázquez $R$, Aparicio $R$, Luque de Leon $E$, Jimenez JM, et al. 12-year old adolescent with super morbid obesity, treated with laparoscopic one anastomosis gastric bypass (LOAGB/BAGUA): A case report after 5-year follow-up. Nutr Hosp. 2015; 31: 2327-2332. PubMed: https://www.ncbi.nlm.nih.gov/pubmed/25929410

93. Carbajo MA, Gonzalez-Ramirez G, Jimenez JM, Luque-de-Leon E, Ortizde-Solorzano J. et al. A 5-Year Follow-up in Children and Adolescents Undergoing One-Anastomosis Gastric Bypass (OAGB) at a European IFSO Excellence Center (EAC- BS).Obes Surg. 2019; 29: 2739-2744. PubMed: https://www.ncbi.nlm.nih.gov/pubmed/31049849

94. Vilallonga R, Moreno JM, Yeste D, Sánchez Santos R, Casanueva Freijo F, et al.: Initial Approach to Childhood Obesity in Spain. A Multisociety Expert Panel Assessment. Obes Surg. 2017; 27: 997-1006. PubMed: https://www.ncbi.nlm.nih.gov/pubmed/27752806

95. Vilallonga R, Fort JM, Caubet E, González O, Armengol M. Robotic Sleeve Gastrectomy Versus Laparoscopic Sleeve Gastrectomy: a Comparative Study with 200 Patients. Obes Surg. 2013; 23: 15011507.

PubMed: https://www.ncbi.nlm.nih.gov/pubmed/23897216

96. Morales S. Bypass gástrico por puerto único: detalles técnicos. De un nuevo abordaje. Cir Es. 2015; 90: 100-106.

97. Morales-Conde S, Peeters A, Meyer YM, Antoniou SA, Del Agua IA, et al. European association for endoscopic surgery (EAES) consensus statement on single-incision endoscopic surgery. Surg Endosc. 2019; 33: 996-1019.

PubMed: https://www.ncbi.nlm.nih.gov/pubmed/30771069

98. Shikora S Torres A: Baltasar. Biography. Obes Surg. 2016; 26: 477-478.

99. Torres AJ. Biography. Obes Surg. 2017; 27: 2383-2384.

100. Baltasar A. Rafael Capella biography. Obes Surg. 2017; 27: 1129.

101. Baltasar A, Luque-de-León E., Carbajo MA. Carbajo biography. Obes Surg. 2018; 28: 889-891.

102. Baltasar A, Bou R, Bengochea M, Serra C. Malnutrición calóricoproteica. Tres tipos de alargamiento de asa común. BMI-Latina. 2011; 5: 96-97.

103. Baltasar A, Bou R, Bengochea M. Fatal perforations in laparoscopic bowel lengthening operations for malnutrition. Surg Obes Relat Dis. 2010; 6: 572-574.

PubMed: https://www.ncbi.nlm.nih.gov/pubmed/20176511

104. Bueno J, Pérez N, Serra C. Fistula pancreato-cutánea secundaria a pancreatitis postoperatoria tras cruce duodenal laparoscópico. Cir Esp. 2004; 76: 184-186.

105. Serra C, Baltasar A, Andreo L, Pérez N, Bou R, et al. Treatment of Gastric Leaks with Coated Self-expanding Stents after Sleeve Gastrectomy. Obes Surg. 2007; 17: 866-872.

PubMed: https://www.ncbi.nlm.nih.gov/pubmed/17894143

106. Serra C, Baltasar A, Pérez N, Bou R, Bengochea M. Total Gastrectomy for Complications of the Duodenal Switch, with Reversal. Obes Surg. 2006; 16: 1082-1086.

PubMed: https://www.ncbi.nlm.nih.gov/pubmed/16901364

107. Castillo J, Fábrega F, Escalante C, Sanjuan JC, Herrera L, et al. Liver Transplantation in a Case of Steatohepatitis and Subacute Hepatic Failure after Biliopancreatic Diversion for Morbid Obesity. Obes Surg. 2001; 11: 640-642.

PubMed: https://www.ncbi.nlm.nih.gov/pubmed/11594111

108. Baltasar A. Liver failure and transplantation after duodenal switch 
Surg Obes Relat Dis. 2014; 10: c93-c96.

PubMed: https://www.ncbi.nlm.nih.gov/pubmed/24916757

109. Mayo Ossorio MA, Pacheco García JM, Gomar DP, del Carmen Bazán Hinojo M, Vílchez López FJ, et al. Caso clínico Fallo hepático fulminante a largo plazo en pacientes sometidos a bypass gástrico por obesidad mórbida. Nutr Hosp. 2015; 32: 430-434.

110. Baltasar A, Bou R, Serra C. Grapado de la sonda en gastrectomía vertical laparoscópica. BMI-latina. 2013; 3: 4-7.
111. Baltasar A, Bou R, Bengochea M. Intubación Difícil y Traqueotomía en el obeso mórbido Baltasar A. BMI. 2013; 3: 4.

112. Baltasar A. Prevenir y Deshacer entuertos en cirugía. J Negative or non-Positive Results. 2019; 4: 252-264.

113. Duncan T, Tuggle K, Larry Hobson L. PL-107. Feasibility of laparoscopic gastric bypass performed on an outpatient basis. Surg Obes Relat Dis. 2011; 7: 339-354. 